Case Report

\title{
Cisplatin and Short-Term 5-Fluorouracil Infusion for Paraneoplastic Microangiopathic Hemolytic Anemia in Gastric Cancer: A Case Report and Review of the Literature
}

\author{
M. S. Sanatani, ${ }^{1}$ A. Lazo-Langner, ${ }^{2,3,4}$ and I. M. Al-Rasheedy ${ }^{5}$ \\ ${ }^{1}$ Department of Medical Oncology, Western University, 790 Commissioners Road East, London, ON, Canada N6A 4L6 \\ ${ }^{2}$ Department of Medicine, Division of Hematology, Western University, 800 Commissioners Road E E6-216, \\ London, ON, Canada N6A 5W9 \\ ${ }^{3}$ Department of Oncology, Western University, 800 Commissioners Road E E6-216, London, ON, Canada N6A 5W9 \\ ${ }^{4}$ Department of Epidemiology and Biostatistics, Western University, 800 Commissioners Road E E6-216, \\ London, ON, Canada N6A 5W9 \\ ${ }^{5}$ Medical Oncology, King Abdulaziz Medical City, Princess Noorah Oncology Center, Jeddah, Saudi Arabia
}

Correspondence should be addressed to M. S. Sanatani; michael.sanatani@lhsc.on.ca

Received 22 October 2013; Accepted 20 November 2013

Academic Editors: L. Beex and S. Ohno

Copyright (c) 2013 M. S. Sanatani et al. This is an open access article distributed under the Creative Commons Attribution License, which permits unrestricted use, distribution, and reproduction in any medium, provided the original work is properly cited.

\begin{abstract}
Microangiopathic hemolytic anemia is a rare paraneoplastic syndrome accompanying adenocarcinoma of the stomach. We report on a patient presenting with anemia due to a combination of severe hemolysis and tumour bleeding, where the combination of cisplatin and 5-fluorouracil in a short course infusional regimen led to a complete response of the hematologic abnormalities in the first line setting. Relapse was successfully treated with second line docetaxel; however the response was relatively short-lived. Overall survival was 16 months from diagnosis, which compares favourably to the survival of other reported cases. The chemotherapy regimens used in previously reported similar cases are reviewed. We suggest that a regimen based on bolus 5-fluorouracil, possibly with a platinum, should be investigated as a possible regimen of choice.
\end{abstract}

\section{Introduction}

Cancer-associated microangiopathic hemolytic anemia (MAHA) is a rare, potentially fatal complication of malignant tumors, usually associated with poor prognosis. It has been reported to occur in gastric, breast, prostate, and lung cancer and also a few cases have been reported in patients with carcinoma of unknown origin [1]. This condition was first described by Brain et al. in 1962 [2]. It is defined as a severe hemolytic anemia in the setting of malignancy with negative Coombs' test and fragmented red blood cells in the peripheral blood smear. The clinical presentation may include features of DIC (disseminated intravascular coagulation), TTP (thrombotic thrombocytopenic purpura), or HUS (hemolytic uremic syndrome) and the distinction between these conditions is usually not straightforward. We report on a case of a patient with severe hemolytic anemia in the setting of metastatic gastric cancer who experienced a complete resolution of the anemia and a marked tumor response after treatment with palliative chemotherapy. Building on a recently published review by Lechner and Obermeier [3], we also review prior reported cases of hemolysis in gastric cancer specifically in regard to the chemotherapy regimen used.

\section{Presentation and Diagnosis}

A 49-year-old previously healthy male was admitted to the hospital with a history of increased dyspnea and fatigue over the course of several weeks. Other history was negative apart from a history of longstanding heartburn that was controlled with proton pump inhibitors and a history of early satiety 


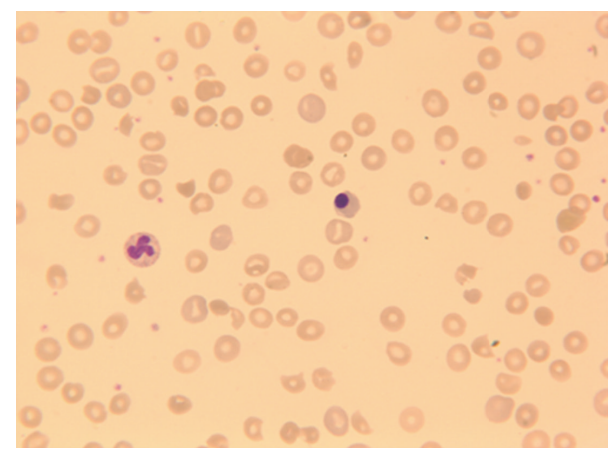

Figure 1: Polychromasia, nucleated red blood cells, and fragments on presentation.

for the last 1-2 years. There was no family history of malignancy. He was diagnosed with severe anemia (hemoglobin $52 \mathrm{~g} / \mathrm{L}$ ) and his peripheral smear showed schistocytes and polychromasia, as well as nucleated red blood cells (Figure 1). Serum free haptoglobin level was undetectable. Coombs' test was negative, bilirubin and $\mathrm{LDH}$ were elevated $(73.1 \mu \mathrm{mol} / \mathrm{L}$ [normal < 17.1] and 917 U/L [normal < 225], resp.), and a diagnosis of MAHA was made. In order to rule out an underlying solid tumor, CT scan of the chest, abdomen, and pelvis was performed demonstrating widespread metastatic disease, with thickening of the stomach and a GE junction mass measuring about $6 \times 3.2 \mathrm{~cm}$ (Figure 2(a)). Gastroscopy was done and confirmed a gastroesophageal junction mass, with the biopsy showing low grade adenocarcinoma.

\section{Initial Treatment Course}

The patient was given transfusions, but his hemoglobin remained persistently below $80 \mathrm{~g} / \mathrm{L}$. He also developed episodes of melena. His laboratory tests showed worsening hemolysis, and after a drop in the platelet count (from $169,000 / \mu \mathrm{L}$ on admission to $76,000 / \mu \mathrm{L}$ after one week) a diagnosis of possible thrombotic thrombocytopenic purpura (TTP) was made and he was started on a trial of daily plasmapheresis without improvement.

Because of the melena, the patient was referred to radiation oncology and was treated with palliative radiotherapy (2000 cGy in 5 fractions) to the primary tumour in the stomach with resolution of the melena, but with no improvement in the transfusion requirements. A decision was made to start palliative chemotherapy with cisplatin and 5fluorouracil (5-FU). A short intense regimen consisting of cisplatin $50 \mathrm{mg} / \mathrm{m}^{2}$ day 1 and 5 -FU infusion $1000 \mathrm{mg} / \mathrm{m}^{2} /$ day, days 1 through 4 , all q21 days, was chosen to minimize days without plasmapheresis. However, during the first cycle plasmapheresis was discontinued due to lack of response, and shortly after the patient's hemoglobin started to stabilize with decreasing transfusion requirements and by three weeks after therapy start, he was no longer transfusion dependent. He was discharged from hospital approximately one month

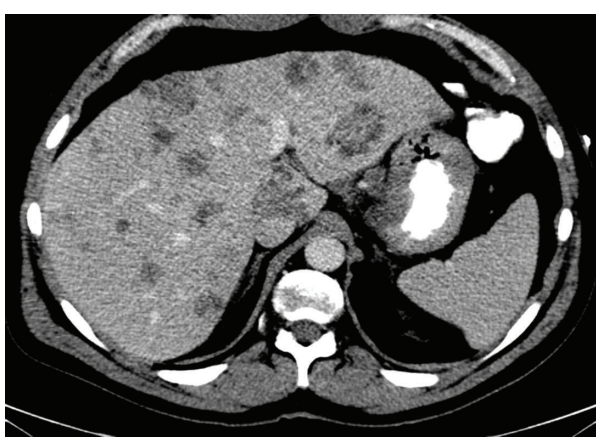

(a)

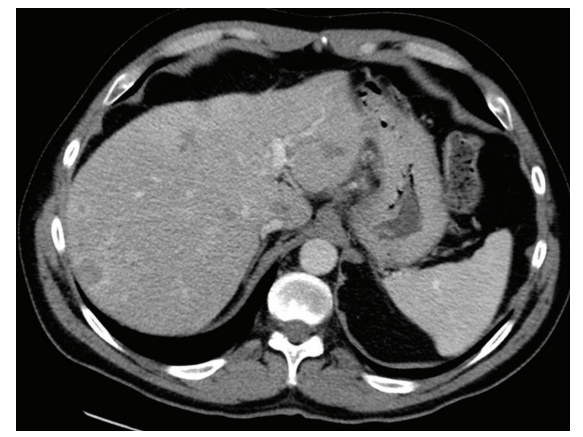

(b)

Figure 2: (a) Computed tomography imaging at presentation. (b) Computed tomography imaging after three cycles of cisplatin/5-FU.

after admission, ambulatory and with improving performance status.

The patient continued on chemotherapy with cisplatin/5FU every three weeks as outlined above. After three cycles of chemotherapy, he was completely asymptomatic (ECOG 0), no longer requiring any transfusions. A CT scan (Figure 2(b)) showed a decrease in the number and size of liver metastases. He completed 10 cycles, after which the treatment was stopped because of worsening sensory neuropathy.

Two months after this last chemotherapy the patient presented on followup with progressive disease in form of recurrent hemolysis and worsening liver metastases, retroperitoneal lymphadenopathy, and a recurrent mass in the GE junction as well as melena. He received a single fraction of palliative radiation to the stomach and was started on second line chemotherapy with DCF (docetaxel $25 \mathrm{mg} / \mathrm{m}^{2}$ weekly, cisplatin $60 \mathrm{mg} / \mathrm{m}^{2}$ q21 days, and $200 \mathrm{mg} / \mathrm{m}^{2}$ 5-FU infusion). The hemoglobin and other indicators of hemolysis stabilized again (Figure 3), and CT scan followup after 3 cycles showed mixed response in the hepatic metastases. He continued the DCF chemotherapy for control of the hemolysis for a total of 6 cycles, with cisplatin and 5FU then omitted due to declining performance status and mucositis (change to single agent docetaxel), but presented later with an intractable GI bleed from the primary tumour. Despite endoscopic intervention by the gastroenterology service he continued to deteriorate and comfort measures were instituted. He died of gastric hemorrhage, 16 months 

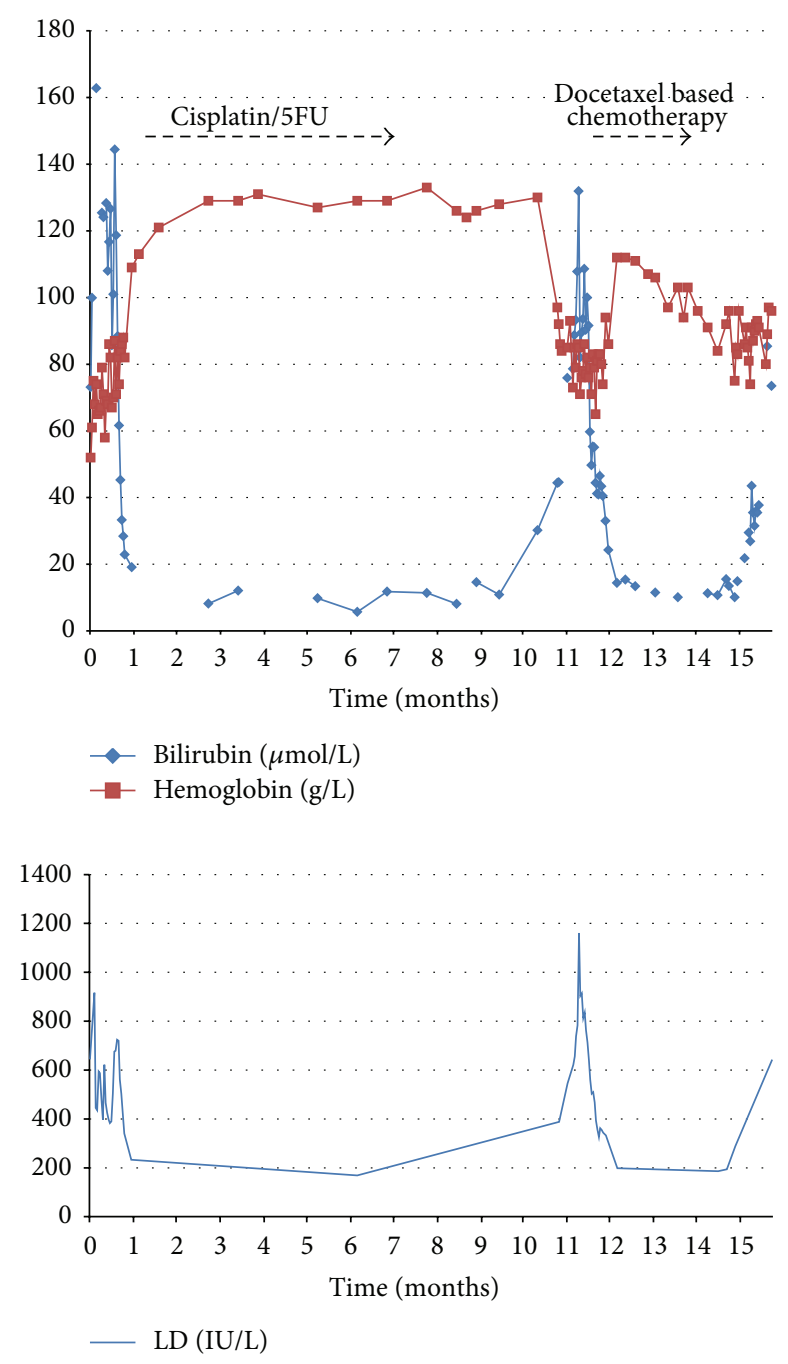

Figure 3: Hemoglobin, total bilirubin, and lactate dehydrogenase levels $(\mathrm{U} / \mathrm{L})$.

from the time of his initial presentation with stage IV gastric adenocarcinoma.

\section{Discussion}

Microangiopathic hemolytic anemia (MAHA) can be the first manifestation of malignancy such as gastroesophageal cancer. Indeed, several case reports [4-6] exist describing curative-intent surgery after diagnosis of an early stage gastric cancer presenting with MAHA. We report on the case of a previously undiagnosed gastroesophageal cancer patient with severe hemolytic anemia requiring up to 5 units daily of blood, in whom chemotherapy resulted in a complete response of the hemolysis and an ongoing response in the tumor burden for over a year. We chose a cisplatin and short-term infusion 5-FU regimen rather than the usual DCF or ECF (epirubicin/cisplatin/5-FU) treatments based on prior case reports $[7,8]$ and also initially to allow plasmapheresis, which however ultimately was abandoned quickly. We also had concerns initially regarding myelosuppression by a 3-agent regimen. Since the tumour was Her2neu negative no trastuzumab therapy was considered.

Published cases of MAHA associated with gastric cancer [3] are detailed in Table 1 [4-36].

Two observations from this summary are worth pointing out.

(1) Diagnosis and Purported Mechanism. There are many reported cases of hemolytic anemia with or without thrombocytopenia in gastric cancer. However, a unifying diagnosis or nomenclature remains elusive. In several cases (including ours) clinical consideration was given to the diagnosis of TTP/HUS. As in many other published cases of CR-MAHA, plasmapheresis was performed; however it did not seem to have a significant effect. Carr et al. [13] have reported on a patient with gastric cancer and TTP where plasmapheresis did improve gastrointestinal bleeding, fever, and mental status changes; however that patient's presentation may have had a different pathophysiological basis than our case. All these observations raise the question of whether malignancyassociated MAHA that is unresponsive to plasmapheresis is a form of TTP/HUS or rather is a completely different disease entity and although some reduction in ADAMTS13 metalloproteinase activity has been reported in cancer patients with hemolysis, this can also be the case in other clinical settings [37]. Levels of von-Willebrand factor cleaving protease are not consistently altered in CR-MAHA associated with thrombocytopenia [12]. Future research into the pathophysiology underlying CR-MAHA, as well as clarification of nomenclature, classification, and distinction between TTP, HUS, DIC, and possibly "CR-MAHA with thrombocytopenia NOS (not otherwise specified)," is urgently required.

(2) Heterogeneity of Management Approaches. A review of the published cases highlights the heterogeneity of the treatment approaches used for patients presenting with hemolysis and gastric cancer and reflects the evolution of systemic therapy for this malignancy over the last three decades. Cytotoxics used, in various combinations, were carboplatin, cisplatin, oxaliplatin, paclitaxel, docetaxel, etoposide, 5-fluorouracil, adriamycin, mitomycin-C, vincristine, methotrexate, cyclophosphamide, gemcitabine, irinotecan, and hydroxyurea. Interestingly, only very few publications $[7,8,26]$ provided all the details of the chemotherapy regimen required to prescribe it. Many patients apparently did not receive chemotherapy because of poor performance status. Based on our experience we would suggest that gastric cancer patients with CR-MAHA may benefit from a trial of chemotherapy, within reason, even though they may appear too ill for this. Our patient had an ECOG (Eastern Cooperative Oncology Group) performance status of 4 when chemotherapy was started but improved to ECOG 0 within a few months. Approximately one quarter of the patients in this review received plasmapheresis, with only one patient deriving clinical benefit [13]. 
TABle 1

\begin{tabular}{|c|c|c|c|c|c|c|c|c|c|}
\hline Reference & Age & $\mathrm{M} / \mathrm{F}$ & $\begin{array}{l}\mathrm{Hb} \\
(\mathrm{g} / \mathrm{L})\end{array}$ & $\begin{array}{l}\text { Platelets } \\
\left(\times 10^{9} / \mathrm{L}\right)\end{array}$ & $\begin{array}{l}\text { Plasma- } \\
\text { pheresis }\end{array}$ & $\begin{array}{l}\text { Hematological } \\
\text { diagnosis }\end{array}$ & Chemotherapy 1st line & $\begin{array}{l}\text { Subsequent } \\
\text { chemotherapy }\end{array}$ & $\begin{array}{c}\text { Approximate } \\
\text { survival from the } \\
\text { beginning of the first } \\
\text { therapy for } \\
\text { hemolysis (if } \\
\text { applicable) or } \\
\text { presentation } \\
\end{array}$ \\
\hline [9] & 70 & M & 72 & 80 & Yes & TTP & Carboplatin/paclitaxel & & 14 days \\
\hline$[10]$ & 52 & $\mathrm{~F}$ & 72 & 62 & No & MAHA & None & & 1 week \\
\hline$[10]$ & 28 & M & 75 & 77 & No & MAHA & None & & 1 week \\
\hline$[10]$ & 21 & M & 61 & 342 & No & MAHA & None & & 1 week \\
\hline [8] & 62 & M & 107 & 86 & No & MAHA & $\begin{array}{c}\text { Etoposide } 120 \mathrm{mg} / \mathrm{m}^{2} \text {, } \\
\text { leucovorin } \\
300 \mathrm{mg} / \mathrm{m}^{2} \text {, and } 5-\mathrm{FU} \\
500 \mathrm{mg} / \mathrm{m}^{2} \text { days } 1-3, \\
\text { every } 21 \text { days }\end{array}$ & $\begin{array}{c}\text { 5-FU } 2000 \mathrm{mg} / \mathrm{m}^{2} \text {, } \\
\text { leucovorin } \\
500 \mathrm{mg} / \mathrm{m}^{2} \\
\text { oxaliplatin } \\
130 \mathrm{mg} / \mathrm{m}^{2} \text { day } 1 \\
\text { every } 14 \text { days }\end{array}$ & 12 months \\
\hline$[11]$ & 19 & M & 100 & 98 & No & MAHA with DIC & $\begin{array}{l}\text { 5-FU, adriamycin, } \\
\text { and mitomycin-C }\end{array}$ & & 6 days \\
\hline$[12]$ & 61 & $\mathrm{~F}$ & 95 est & NR & No & $\begin{array}{l}\text { Cancer-related } \\
\text { thrombotic } \\
\text { microangiopathy }\end{array}$ & $\begin{array}{l}\text { Infusional 5-FU } \\
250 \mathrm{mg} / \mathrm{m}^{2} / \text { day }\end{array}$ & & 35 days \\
\hline$[13]$ & 60 & M & 82 & 43 & Yes & TTP & $\begin{array}{l}\text { 5-FU, adriamycin, } \\
\text { and mitomycin } \mathrm{C}\end{array}$ & & 6 months \\
\hline$[14]$ & 59 & $\mathrm{~F}$ & 61 & 20 & Yes & TTP & None & & 1 month \\
\hline$[14]$ & 65 & $\mathrm{~F}$ & 80 & 86 & No & TTP & Paclitaxel & & 11 months \\
\hline$[15]$ & 52 & M & 60 & 24 & Yes & $\begin{array}{l}\text { MAHA without } \\
\text { DIC }\end{array}$ & None & & 4 weeks \\
\hline$[16]$ & 75 & M & 81 & NR & No & MAHA & None & & 20 days \\
\hline [17] & 58 & $\mathrm{~F}$ & 58 & 14 & No & MAHA & $\begin{array}{l}\text { 5-FU, vincristine, } \\
\text { methotrexate, and } \\
\text { cyclophosphamide }\end{array}$ & & 10 days \\
\hline$[18]$ & 50 & M & 73 & 50 & Yes & $\begin{array}{c}\text { Cancer-associated } \\
\text { MAHA }\end{array}$ & $\begin{array}{c}\text { Docetaxel, 5-FU, and } \\
\text { platinum }\end{array}$ & & 12 days \\
\hline [4] & 71 & $\mathrm{M}$ & 44 & 18 & No & TTP & None & & $\begin{array}{l}\text { Curative-intent } \\
\text { surgery }\end{array}$ \\
\hline [19] & 25 & $\mathrm{~F}$ & 74 & 100 & No & MAHA & $\begin{array}{c}5 \text {-FU } 600 \mathrm{mg} / \mathrm{m}^{2} \\
\text { weekly + adriamycin } \\
40 \mathrm{mg} / \mathrm{m}^{2} \text { day } 1, \mathrm{q} 21 \\
\text { days }\end{array}$ & $\begin{array}{c}\text { Mitomycin-C } \\
10 \mathrm{mg} / \mathrm{m}^{2} \text { monthly }\end{array}$ & 7 months \\
\hline [20] & 28 & $\mathrm{~F}$ & 52 & 111 & Yes & TTP & $\begin{array}{l}\text { Cisplatin/5-FU } \\
\text { infusion }\end{array}$ & & Under 2 months \\
\hline [7] & 45 & $\mathrm{M}$ & 59 & 50 & No & $\begin{array}{l}\text { MAHA and } \\
\text { thrombocytopenia }\end{array}$ & $\begin{array}{c}\text { Cisplatin } 60 \mathrm{mg} / \mathrm{m}^{2} \\
\text { day } 1,5-\mathrm{FU} \\
600 \mathrm{mg} / \mathrm{m}^{2} / \text { day } \\
\text { infusion days } 1-4, \\
\text { every } 21 \text { days }\end{array}$ & & 7 weeks \\
\hline [7] & 32 & $\mathrm{~F}$ & NR & NR & Yes & $\begin{array}{l}\text { MAHA and } \\
\text { thrombocytopenia }\end{array}$ & $\begin{array}{l}\text { Cisplatin } 20 \mathrm{mg} / \mathrm{m}^{2} \\
\text { days } 1-5 \text {, etoposide } \\
60 \mathrm{mg} / \mathrm{m}^{2} \text { days } 1-5, \\
\text { every } 21 \text { days }\end{array}$ & $\begin{array}{c}5 \text {-FU } 298(=70 \% \text { of } \\
425) \mathrm{mg} / \mathrm{m}^{2} \text { and } \\
\text { leucovorin } \\
20 \mathrm{mg} / \mathrm{m}^{2} \text { days } 1-5 \text {, } \\
\text { and weekly } \\
\text { cetuximab } 500 \mathrm{mg} \\
\text { IV, all every } 21 \text { days }\end{array}$ & 12 weeks approx.. \\
\hline
\end{tabular}


TABle 1: Continued.

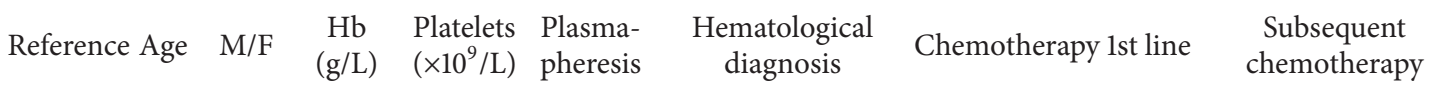

Approximate

survival from the

beginning of the first

therapy for

hemolysis (if

applicable) or

presentation
Mitomycin-C $10 \mathrm{mg}$
and neothramycin
(also gabexate
infusion), 5 doses
over 2 months

3 months

[5] $\quad \begin{array}{llllll}71 & \mathrm{~F} & 56 & 15.6 & \text { No } & \text { MAHA }\end{array}$

Thrombotic

[6] $\quad \begin{array}{llllll}69 & \mathrm{M} & 65 & 64 & \text { Yes } & \text { microangiopathy }\end{array}$ with renal failure

[21] $\quad \begin{array}{lllll}60 & \mathrm{M} & 98 & 35 & \text { No }\end{array}$

$\left[\begin{array}{llllll}{[22]} & 83 & F & 40 & 85 & \text { No }\end{array}\right.$

$\left[\begin{array}{llllll}{[23} & 47 & \text { F } & 49 & 9 & \text { No }\end{array}\right.$

$\left[\begin{array}{llllll}\text { [24] } & 69 & \mathrm{~F} & 96 & 104 & \text { No }\end{array}\right.$

[25] $\quad \begin{array}{llll}44 & \mathrm{M} & 74 & 71\end{array}$

[26] $\quad \begin{array}{lllll}57 & \mathrm{M} & 58 & 39 & \text { No }\end{array}$

[27] $\quad \begin{array}{lllll}52 & \mathrm{~F} & 68 & 18 & \text { No }\end{array}$

[27] $\quad \begin{array}{lllll}51 & \mathrm{M} & 74 & 74 & \text { No }\end{array}$

[27] $\quad 59 \quad$ M $\quad 66 \quad 39 \quad$ Yes

[28] $\quad \begin{array}{lllll}51 & \text { F } & 67 & 40 & \text { Yes }\end{array}$

[29] $\quad \begin{array}{lllll}59 & \text { F } & 86 & 23 & \text { No }\end{array}$

$\left[\begin{array}{llllll}{[29]} & 51 & F & 39 & 120 & \text { No }\end{array}\right.$

[29] $46 \quad \mathrm{~F} \quad 115 \quad 59 \quad$ No

[30] $43 \quad \mathrm{M} \quad 53 \quad$ NR $\quad$ No

$\begin{array}{llllll}\text { [31] } & 66 & \mathrm{M} & 70 & 250 & \mathrm{No}\end{array}$

$\begin{array}{llllll}\text { [32] } & \text { NR } & \text { NR } & 43 & 45 & \text { No }\end{array}$

$\begin{array}{llllll}{[33} & 50 & \mathrm{M} & 85 & 95 & \mathrm{No}\end{array}$
DIC

MHA

MAHA

MAHA

MAHA and DIC

DIC

Thrombotic microangiopathy

Thrombotic microangiopathy

Thrombotic microangiopathy

TTP

DIC

DIC

DIC

HUS

MAHA

$$
\begin{gathered}
\text { 5-FU } 425 \mathrm{mg} / \mathrm{m}^{2} \text { and } \\
\text { leucovorin } 20 \mathrm{mg} / \mathrm{m}^{2} \\
\text { daily }
\end{gathered}
$$

Cisplatin/5-FU

MAHA

Pulmonary

tumour

Thrombotic microangiopathy

None

None

Cisplatin $80 \mathrm{mg} / \mathrm{m}^{2}$ day $1,5-F U$ 1-5

Adriamycin

None

Methotrexate $100 \mathrm{mg} / \mathrm{m}^{2}$ day 1

5-FU bolus

$600 \mathrm{mg} / \mathrm{m}^{2}$ day $1, \mathrm{LV}$

$10 \mathrm{mg} / \mathrm{m}^{2} \mathrm{q} 6 \mathrm{~h}$ days 2 and 3 , weekly

5-FU, cisplatin, and hydroxyurea

Gemcitabine, oxaliplatin, irinotecan, 5-FU, and docetaxel (details not reported)

None

5-FU 250 mg daily, mitomycin C $7 \mathrm{mg}$ weekly, and cisplatin
N/A

$1000 \mathrm{mg} / \mathrm{m}^{2} /$ day, days $20 \%$ dose reduction

44 days

Cisplatin $50 \mathrm{mg} / \mathrm{m}^{2}$ days $1+15$, 5-FU $150 \mathrm{mg} / \mathrm{m}^{2}$, and LV

Curative intent surgery

24 days

3 days

19 months

4 weeks

3 months

10 months

3 months

4 months $500 \mathrm{mg}$ weekly

3 months

10 days

22 days

8 days

Surgery, no recurrence

5 -FU $425 \mathrm{mg} / \mathrm{m}^{2}$ and leucovorin $20 \mathrm{mg} / \mathrm{m}^{2}$ daily

26 months

2 days

86 days 
TABle 1: Continued.

\begin{tabular}{|c|c|c|c|c|c|c|c|c|c|}
\hline Reference & Age & $\mathrm{M} / \mathrm{F}$ & $\begin{array}{l}\mathrm{Hb} \\
(\mathrm{g} / \mathrm{L})\end{array}$ & $\begin{array}{l}\text { Platelets } \\
\left(\times 10^{9} / \mathrm{L}\right)\end{array}$ & $\begin{array}{l}\text { Plasma- } \\
\text { pheresis }\end{array}$ & $\begin{array}{c}\text { Hematological } \\
\text { diagnosis }\end{array}$ & Chemotherapy 1st line & $\begin{array}{c}\text { Subsequent } \\
\text { chemotherapy }\end{array}$ & $\begin{array}{c}\text { Approximate } \\
\text { survival from the } \\
\text { beginning of the first } \\
\text { therapy for } \\
\text { hemolysis (if } \\
\text { applicable) or } \\
\text { presentation } \\
\end{array}$ \\
\hline$[34]$ & 66 & M & 73 & 28 & No & Hemol. anemia & None & & 15 days \\
\hline$[34]$ & 43 & M & 91 & 50 & & Hemol. anemia & None & & 7 days \\
\hline [35] & 43 & M & 78 & 62 & No & DIC/MAHA & $\begin{array}{c}\text { MMC, 5-FU, Ara-C, } \\
\text { and heparin }\end{array}$ & & 6 months \\
\hline$[36]$ & 27 & $\mathrm{~F}$ & 72 & 23 & Yes & $\begin{array}{l}\text { Thrombotic } \\
\text { microangiopathy }\end{array}$ & None & & 3 days \\
\hline Our case & 49 & M & 52 & 76 & Yes & CR-MAHA & $\begin{array}{c}\text { Cisplatin } \\
50 \mathrm{mg} / \mathrm{m}^{2} \text { day } 1,5-\mathrm{FU} \\
\text { infusion } \\
1000 \mathrm{mg} / \mathrm{m}^{2} / \text { day, days } \\
1 \text { through } 4 \text {, all every } \\
21 \text { days }\end{array}$ & $\begin{array}{c}\text { Docetaxel } 25 \mathrm{mg} / \mathrm{m}^{2} \\
\text { weekly, cisplatin } \\
60 \mathrm{mg} / \mathrm{m}^{2} \text { every } 21 \\
\text { days, and } \\
200 \mathrm{mg} / \mathrm{m}^{2} 5 \text {-FU } \\
\text { infusion daily }\end{array}$ & 16 months \\
\hline
\end{tabular}

CR: cancer-related; DIC: disseminated intravascular coagulation; 5-FU: 5-fluorouracil; HUS: hemolytic uremic syndrome; MAHA: microangiopathic hemolytic anemia; MMC: mitomycin-C; TTP: thrombotic thrombocytopenic purpura.

(3) Is There an "Anecdotally Best" Treatment Approach? Based on our case as well as the review of other cases, we would suggest several management principles for future cases. In regard to diagnosis, to avoid confusion, an overall inclusive diagnostic term for a condition presenting with evidence of hemolysis, negative Coombs' test, thrombocytopenia, gastric malignancy known or suspected, and absence of renal failure or mental status changes may be "gastric-cancer-associated MAHA with thrombocytopenia." On establishing that diagnosis, it would appear that rapid initiation of chemotherapy is of greater importance than that of plasmapheresis. This may not apply in cases where the presentation has most of the features of classical TTP or HUS including hemorrhage or renal or nervous system dysfunction.

Second, it would appear that chemotherapy regimens including cisplatin as well as bolus 5-fluorouracil (our patient, $[7,8,23,31])$ may be the treatment of choice as anecdotally patients treated with such regimens had superior survival in the cases reviewed here. Third, chemotherapy should perhaps be continued in situations where it usually would not be, (e.g., despite developing adverse events and tumour growth). In retrospect, even though our patient eventually did have a relatively long survival, it is conceivable that continuing chemotherapy despite the worsening neuropathy could have had a beneficial effect on preventing the recurrence of the hemolysis. We also demonstrated control of hemolysis in the setting of progressive tumour growth on second line chemotherapy, although the duration of control was much shorter in this setting ( 6 versus 10 cycles on first line therapy with ongoing tumour control).

Further research into the etiology and mechanism of malignancy-associated MAHA and its connection to TTP/ HUS, as well as development of consistent terminology and diagnostic criteria, may shed some further light on management of similar cases in the future.

\section{Conflict of Interests}

The authors declare that there is no conflict of interests regarding the publication of this paper.

\section{References}

[1] K. H. Antman, A. T. Skarin, R. J. Mayer, H. K. Hargreaves, and G. P. Canellos, "Microangiopathic hemolytic anemia and cancer: a review," Medicine, vol. 58, no. 5, pp. 377-384, 1979.

[2] M. C. Brain, J. V. Dacie, and D. O. Hourihane, "Microangiopathic haemolytic anaemia: the possible role of vascular lesions in pathogenesis," British Journal of Haematology, vol. 8, pp. 358374, 1962.

[3] K. Lechner and H. L. Obermeier, "Cancer-related microangiopathic hemolytic anemia. Clinical and laboratory features in 168 reported cases," Medicine, vol. 91, pp. 195-205, 2012.

[4] P. Girard, B. Tardy, Y. Page, J. F. Mosnier, B. Tardy-Poncet, and J. C. Bertrand, "Cancer presenting as thrombotic thrombocytopenic purpura. Two case reports," Presse Medicale, vol. 24, no. 3, pp. 175-178, 1995.

[5] T. Kanou, Y. Nosou, K. Yoshinaka et al., "Microangiopathic hemolytic anemia associated with gastric cancer," Gan No Rinsho, vol. 32, no. 9, pp. 1029-1034, 1986.

[6] G. Lakshminarayana, R. Rajesh, N. V. Seethalekshmy, G. Kurian, and V. N. Unni, "Thrombotic microangiopathy with severe renal failure in adenocarcinoma," Indian Journal of Nephrology, vol. 18, pp. 74-76, 2008.

[7] O. Kaidar-Person, H. Nasrallah, N. Haim, E. J. Dann, and G. Bar-Sela, "Disseminated carcinoma diagnosed by bone marrow 
biopsy in patients with microangiopathic hemolytic anemia and thrombocytopenia: a report of two cases with gastric cancer and a review of the literature," Journal of Gastrointestinal Cancer, vol. 42, no. 3, pp. 123-126, 2011.

[8] H.-T. Arkenau, O. Müssig, T. Buhr, H. H. Jend, and R. Porschen, "Microangiopathic hemolytic anemia (MAHA) as paraneoplastic syndrome in metastasized signet ring cell carcinomas: case reports and review of the literature," Zeitschrift fur Gastroenterologie, vol. 43, no. 8, pp. 719-722, 2005.

[9] A. Alexopoulou, S. P. Dourakis, and E. Nomikou, "Case of thrombotic thrombocytopenic purpura associated with disseminated gastric cancer," American Journal of Clinical Oncology, vol. 25, no. 6, p. 632, 2002.

[10] N. Ali, N. Kamran, S. Adil, and S. Pervez, "Metastatic signet ring gastric adenocarcinoma presenting with microangiopathic hemolytic anemia," Indian Journal of Gastroenterology, vol. 26, no. 4, pp. 185-186, 2007.

[11] A. Bisetti, M. Lalicata, and E. Jacot-des-Combes, "Occult gastric adenocarcinoma with pulmonary lymphangitic carcinomatosis and microangiopathic hemolytic anemia in a young adult," Schweizerische Medizinische Wochenschrift, vol. 115, no. 16, pp. 561-564, 1985.

[12] E. Blot, D. Decaudin, A. Veyradier, A. Bardier, O.-L. Zagame, and P. Pouillart, "Cancer-related thrombotic microangiopathy secondary to Von Willebrand factor-cleaving protease deficiency," Thrombosis Research, vol. 106, no. 2, pp. 127-130, 2002.

[13] D. J. Carr, B. S. Kramer, and D. E. Dragonetti, “Thrombotic thrombocytopenic purpura associated with metastatic gastric adenocarcinoma: successful management with plasmapheresis," Southern Medical Journal, vol. 79, no. 4, pp. 476-479, 1986.

[14] J. C. Chang and T. Naqvi, "Thrombotic thrombocytopenic purpura associated with bone marrow metastasis and secondary myelofibrosis in cancer," Oncologist, vol. 8, no. 4, pp. 375-380, 2003.

[15] P. Chevalet, A. Moreau, F. Muller, J. M. Berthelot, M. Hamidou, and A. Prost, "Extensive bone marrow necrosis and thrombotic microangiopathy revealing disseminated adenocarcinoma," Presse Medicale, vol. 27, no. 24, pp. 1213-1215, 1998.

[16] E. Crespo-Valadés, M. P. Espinosa-Magro, and C. MarcoSchulke, "Metastatic adenocarcinoma with microangiopathic hemolytic anemia," Revista Espanola de Enfermedades Digestivas, vol. 102, no. 8, pp. 511-512, 2010.

[17] C. Della Pietra, F. Gudat, P. Obrecht, and D. Hartmann, "Microangiopathic hemolytic anemia in disseminated carcinoma," Schweizerische Medizinische Wochenschrift, vol. 108, no. 10, pp. 357-362, 1978.

[18] M. A. Elliott, L. Letendre, D. A. Gastineau, J. L. Winters, R. K. Pruthi, and J. A. Heit, "Cancer-associated microangiopathic hemolytic anemia with thrombocytopenia: an important diagnostic consideration," European Journal of Haematology, vol. 85, no. 1, pp. 43-50, 2010.

[19] R. M. Hansen and G. A. Hanson, "Gastric carcinoma in young people. A case report and review of the literature," American Journal of Gastroenterology, vol. 74, no. 6, pp. 497-503, 1980.

[20] G. Kadikoylu, S. Barutca, C. Tataroglu et al., "Thrombotic thrombocytopenic purpura as the first manifestation of metastatic adenocarcinoma in a young woman," Transfusion and Apheresis Science, vol. 42, no. 1, pp. 39-42, 2010.

[21] F. J. Laso, M. González-Díaz, J. I. Paz, and S. de Castro, "Bone marrow necrosis associated with tumor emboli and disseminated intravascular coagulation," Archives of Internal Medicine, vol. 143, no. 11, p. 2220, 1983.

[22] K. M. Ludmerer and J. M. Kissane, "Microangiopathic anemia and disseminated intravascular coagulation in an elderly woman," American Journal of Medicine, vol. 74, no. 6, pp. 10521060, 1983.

[23] A. J. M. Martin, P. G. Alfonso, M. C. R. Martinez et al., "Microangiopathic hemolytic anemia and diffuse bone metastasis by signet ring cell adenocarcinoma," Journal of Cancer Therapy, vol. 1, pp. 94-96, 2010.

[24] H. Mauron and R. Streuli, "Anemia, subcutaneous bleeding and weight loss. Disseminated metastasizing, mucinous adenocarcinoma of the stomach," Schweizerische Rundschau fur Medizin Praxis, vol. 89, no. 39, pp. 1568-1572, 2000.

[25] I. Mizuno, O. Izeki, S. Nakahara et al., "Disseminated carcinomatosis of the bone marrow occurring 11 years after subtotal gastrectomy for gastric cancer," Rinshō Ketsueki, vol. 39, no. 9, pp. 670-675, 1998.

[26] N. Noda, T. Sano, K. Shirao et al., "A case of bone marrow recurrence from gastric carcinoma after a nine-year disease-free interval," Japanese Journal of Clinical Oncology, vol. 26, no. 6, pp. $472-475,1996$.

[27] L. Oberic, M. Buffet, M. Schwarzinger et al., "Cancer awareness in atypical thrombotic microangiopathies," Oncologist, vol. 14, no. 8, pp. 769-779, 2009.

[28] Z. K. Otrock, A. T. Taher, J. A. Makarem, M. M. Kattar, G. Nsouli, and A. I. Shamseddine, "Thrombotic thrombocytopenic purpura and bone marrow necrosis associated with disseminated gastric cancer," Digestive Diseases and Sciences, vol. 52, no. 6, pp. 1589-1591, 2007.

[29] E. Pasquini, L. Gianni, E. Aitini et al., "Acute disseminated intravascular coagulation syndrome in cancer patients," Oncology, vol. 52, no. 6, pp. 505-508, 1995.

[30] O. Ortega Marcos, F. Escuin, J. L. Miguel et al., "Hemolytic uremic syndrome in a patient with gastric adenocarcinoma: partial recovery of renal function after gastrectomy," Clinical Nephrology, vol. 24, pp. 265-268, 1985.

[31] M. Ozgüroglu, F. Demirelli, and N. M. Mandel, "Microangiopathic hemolytic anemia as an early predictor of recurrence in gastric cancer," American Journal of Clinical Oncology, vol. 22, no. 2, p. 214, 1999.

[32] M. J. Rauh, A. Al Habeeb, and H. Chang, "Microangiopathic hemolytic anemia and leukoerythroblastic blood film heralding bone marrow metastatic gastroesophageal adenocarcinoma," Pathology Research and Practice, vol. 207, no. 2, pp. 121-123, 2011.

[33] Y. Sato, K. Marutsuka, Y. Asada, M. Yamada, T. Setoguchi, and A. Sumiyoshi, "Pulmonary tumor thrombotic microangiopathy," Pathology International, vol. 45, no. 6, pp. 436-440, 1995.

[34] R. Susano, L. Caminal, J. Ferro, A. Rubiales, J. de Lera, and J. F. de Quirós, "Microangiopathic hemolytic anemia associated with neoplasms: an analysis of 5 cases and a review of the literature," Revista Clinica Espanola, vol. 194, no. 8, pp. 603-606, 1994.

[35] R. Takeuchi, M. Kuto, N. Katayama et al., "Carcinomatosis associated with microangiopathic hemolytic anemia and disseminated intravascular coagulation: 12 years after gastrectomy for gastric adenocarcinoma," Rinsho Ketsueki, vol. 24, no. 10, pp. 1423-1429, 1983.

[36] R. Vasko, M. Koziolek, L. Füzesi, F. König, F. Strutz, and G. A. Müller, "Fulminant plasmapheresis-refractory thrombotic 
microangiopathy associated with advanced gastric cancer," Therapeutic Apheresis and Dialysis, vol. 14, no. 2, pp. 222-225, 2010.

[37] I. Spoormans, S. Altintas, J. van den Brande, A. Luijks, and J. B. Vermorken, "Purpura in a patient with disseminated breast cancer: a rapidly progressive cancer-related thrombotic thrombocytopenic purpura," Annals of Oncology, vol. 19, no. 6, pp. 1204-1207, 2008. 


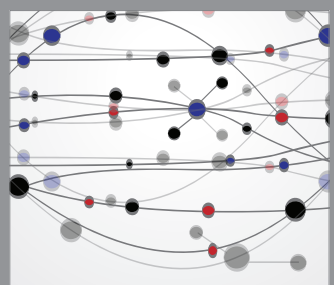

The Scientific World Journal
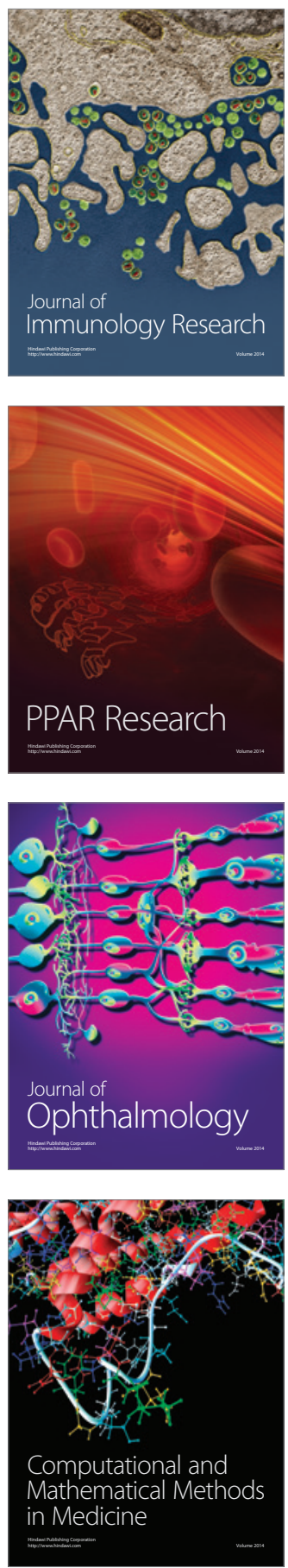

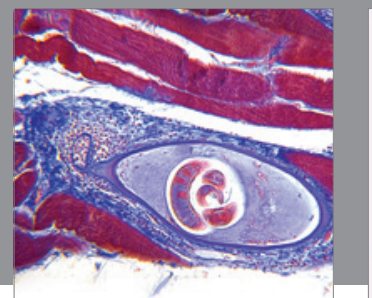

Gastroenterology

Research and Practice
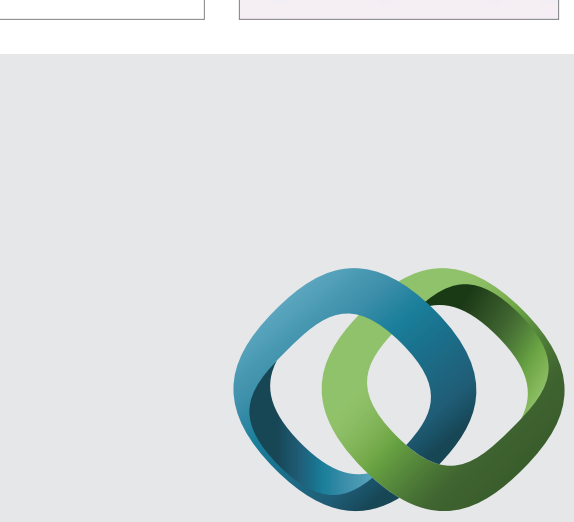

\section{Hindawi}

Submit your manuscripts at

http://www.hindawi.com
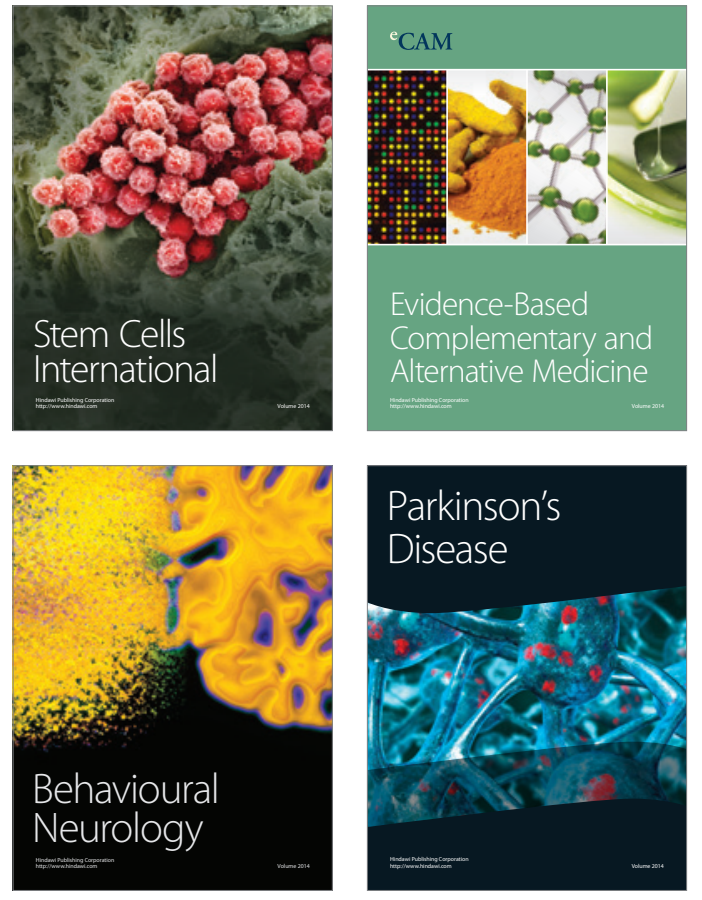
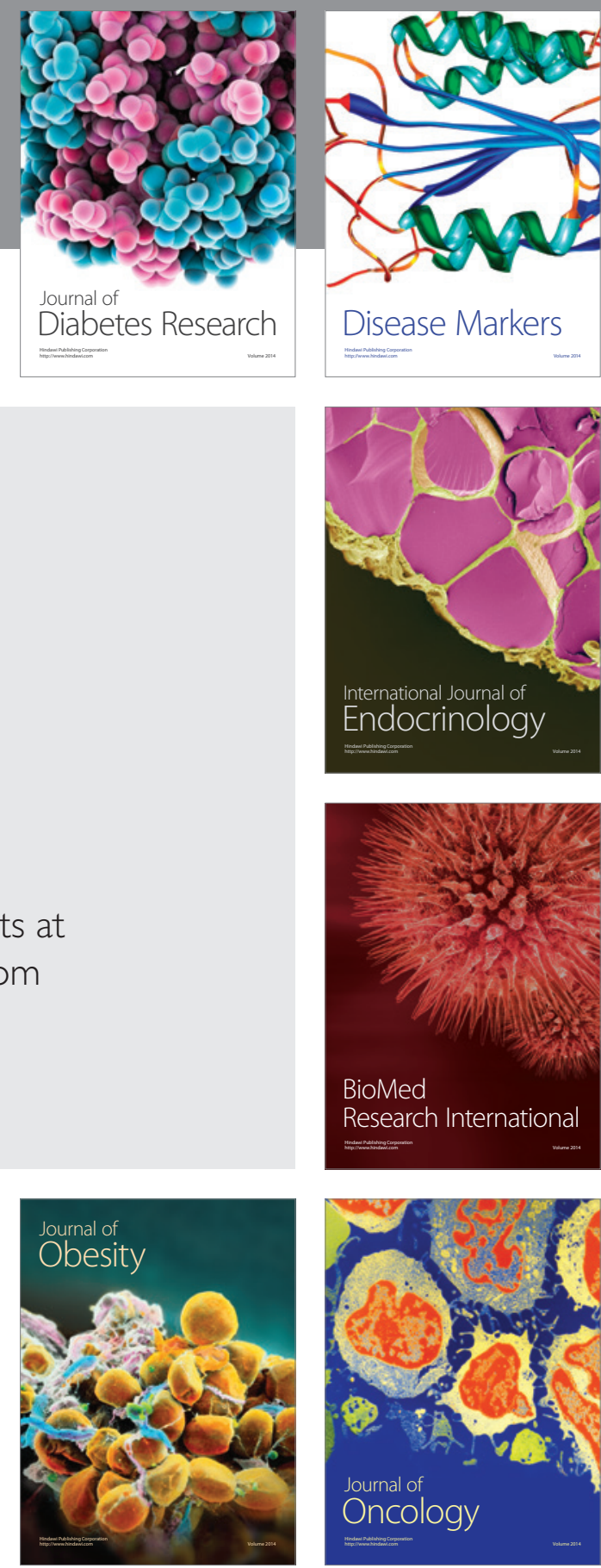

Disease Markers
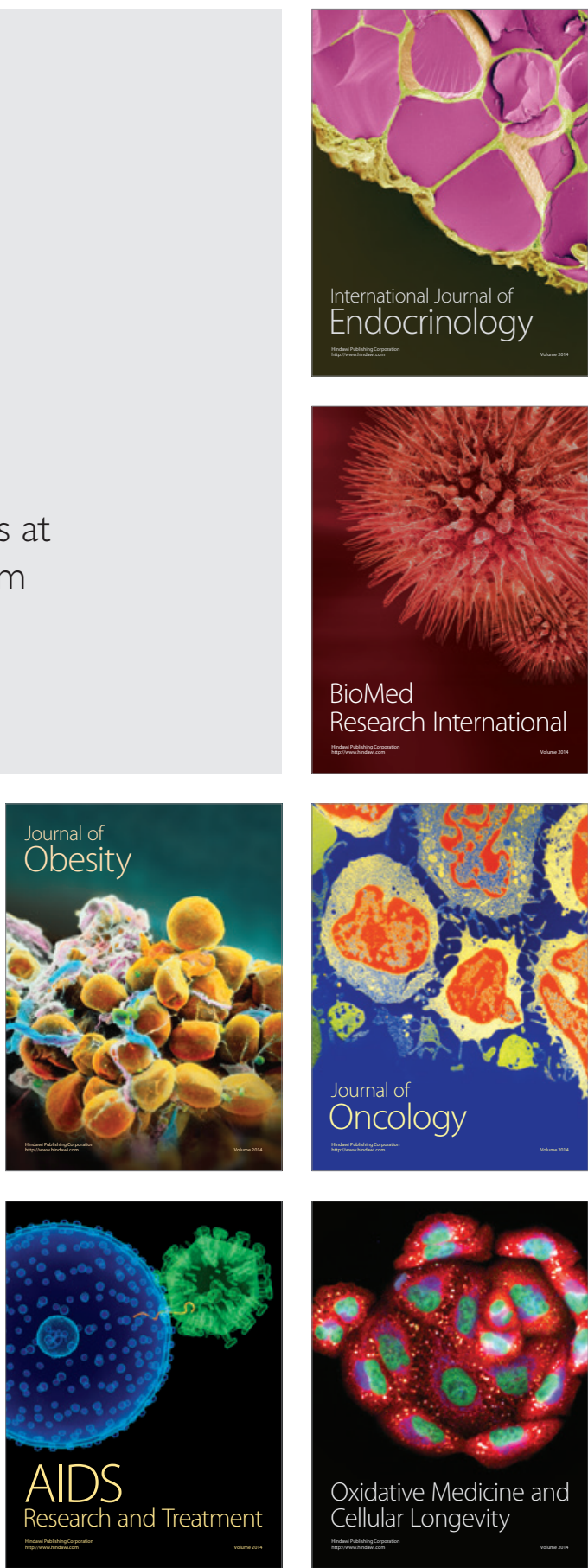